TEME, г. XLIII, бр. 4, октобар - децембар 2019, стр. 1233-1244

Прегледни рад https://doi.org/10.22190/TEME191113074T

Примљено: 13. 11. 2019.

UDK 327:911.3

Ревидирана верзија: 13. 11. 2019.

Одобрено за штампу: 1. 12. 2019.

\title{
NATIONAL AND INTERNATIONAL SECURITY AND CORPORATE GOVERNANCE
}

\section{Darko Trifunović}

Institute for national and international security, Belgrade, Serbia darko@intelligence-security.rs

\begin{abstract}
Corporate governance is a complex process that represents a relatively new concept in the countries in transition, as is the case in the Balkans. A particularly important phenomenon is that of company managers, running state-property companies, mostly in the company's success, but largely invested in their personal gain and self-promotion. It is often the case that they sign detrimental contracts for their own profit, therefore, jeopardize, and weaken the entire economic system of a country, which represents a serious security risk. Modern cooperative governance assumes an entire set of security measures that have to be undertaken in respect to the degree of threats that may jeopardize the profit and success of a company.
\end{abstract}

Key words: security, corporations, governance, threats, risks, assessments.

\section{НАЦИОНАЛНА И МЕЪУНАРОДНА БЕЗБЕДНОСТ И КОРПОРАТИВНО УПРАВЉАҢЕ}

\begin{abstract}
Апстракт
Корпоративно управљање представља сложен процес који је релативно нов концепт у земљама у транзицији, као што је то случај на Балкану. Менаџери који су углавном били незаинтересовани за успех компаније, али само због сопственог интересовања и самопромоције, водили су компаније које су биле, или су још увек, у државној својини. Често се догађа да они закључе лоше уговоре ради сопствене добити, стога угрожавају и ослабљују читав економски систем земље, што представља озбиљан безбедносни ризик. Модерно корпоративно управљање такође претпоставља читав низ безбедносних мера које се морају предузети у вези са степеном претњи које могу угрозити профит и успех компаније.
\end{abstract}

Кључне речи: безбедност, корпорације, управљање, претње, ризици, процена. 


\section{INTRODUCTION}

Corporate governance is a complex process that represents a relatively new concept, especially when it comes to the countries in transition. The level of success and economic development of a country can be assessed according to the applied models of corporate governance. When it comes to public and social companies in the countries that are in the transition process from the socialist to the capitalist way of managing, the model of corporate governance has certain similarities to the capitalist model. In fact, when it comes to their initial capital, public and social companies use state funds, as well as different management structure and control. The process of transition from social to the joint stock ownership, as well as changes in the ownership structure of companies, became the source of various kinds of manipulation and abuse, especially in the case of former Yugoslavian countries. Generally speaking, corporate governance involves the process of managing a company. For the purposes of this work, I would like to highlight the following definition of corporate governance. Corporate governance generally refers to the legal and organizational framework within which a corporation governs principles and processes. It specifically refers to the powers, accountability and relationships of those who participate in the direction and control of a company. There are aspects of corporate governance that have an impact on the relationship between shareholders and the company ${ }^{1}$. The essence of corporate governance refers to the responsibility of the management to the owners of stocks or shareholders. In addition to that, from the definition, we are able to see that corporate governance depends on legal regulations, rules, contracts and norms focused on the existence and action of a company in terms of the market economy.

Diagram 1 shows the difference in corporate governance between the capitalist and socialist organization and management of a company. The Balkan countries are still in the stage of transition and it is becoming obvious that the companies are managed quite differently, primarily taking into consideration the principles of the free market. In most of the Balkans countries, the process of transition from state to the market economy is almost finished. The foreign investment, political will and the system of education all push the economy into the direction of the completion of these processes.

\footnotetext{
${ }^{1}$ Report of the HIH Royal Commission (Owen Report) The Failure of HIH Insurance Volume I: A Corporate Collapse and its Lessons, Canberra, Commonwealth of Australia, 2003, p. xxxiii.
} 


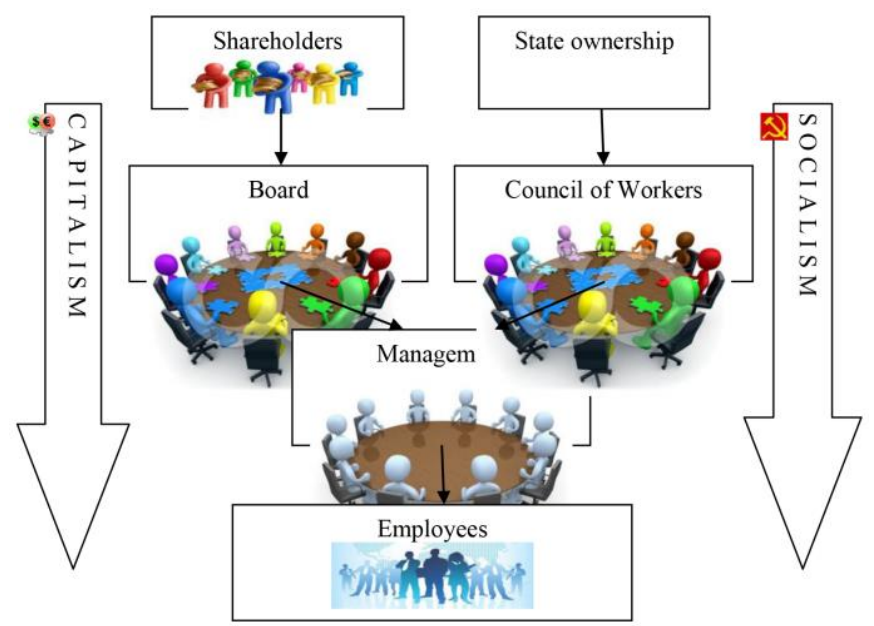

Diagram 1. Corporate governance in capitalism and socialism ${ }^{2}$

The socialist system of corporate governance is one of the important reasons for the collapse and the economic stagnation in the countries that have applied it. Managers who were mostly uninterested for the company's success, but only for their own interest and self-promotion, ran companies that were, or still are, in the state property. It is often the case that they sign detrimental contracts for their own profit and therefore, jeopardize and weaken the entire economic system of a country, which represents a serious security risk. However, corporate governance has been improved in marketoriented economies, and it is extremely important to pay attention to all the potential risks with regard to the state security, and in some cases, international security. The case of a multinational company Enron leads us to the need to establish a new system of rules and guidelines focused on how to run businesses, with a focus on security issues (Eicher, 2009, p.32). Regardless of theory (and there are four theories in this regard - Agency Theory, Stewardship Theory, Stakeholders Theory and Sociological Theory (Banerjee, 2010, p.917)) and models of corporate governance (The Anglo American Model, German Model and Japanese Model (Brink, 1998, p.151)) in modern conditions, more attention has been focused on the security aspects related to the work of one company. These security aspects can no longer refer exclusively to the internal processes of the companies, but also have to follow all those processes outside the company. Therefore, corporate governance involves a much wider range of activities. Corporate governance is something much broader to include a fair, efficient and transparent administration to meet certain well-defined objectives. It is a system of

${ }^{2}$ Diagram 1. Corporate governance in capitalism and socialism - source - author. 
structuring, operating and controlling a company, with the view of achieving long term strategic long goals to satisfy shareholders, creditors, employees, customers and suppliers and to comply with legal and regulatory requirements, apart from meeting environmental and local community needs (Rao, 1998,. p. 151). Modern corporate governance also involves a response to the security challenges that a company faces. In the meantime, security management has become part of the highest hierarchy of corporate governance and the adequate response is solved systematically. Corporate governance includes a wide range of measures in the security field, including security risks that may jeopardize the company's work. Security management of the company detects security risks, both internal and external. Upon risk detection, the next step is to allocate the risk holders, and according to them, determine which steps should be taken, the objective being the protection of the company's work.

\section{CORPORATE GOVERNANCE AND SECURITY}

In corporate management, security can be seen in a narrow and broad sense. In a narrow sense, security implies all the measures that are related to the safe work within a company. On the other hand, the broad concept of security involves all the works and processes on the activities outside the company. Moreover, as a broad concept, corporate security can also be seen through the position of one company in the system of national security.

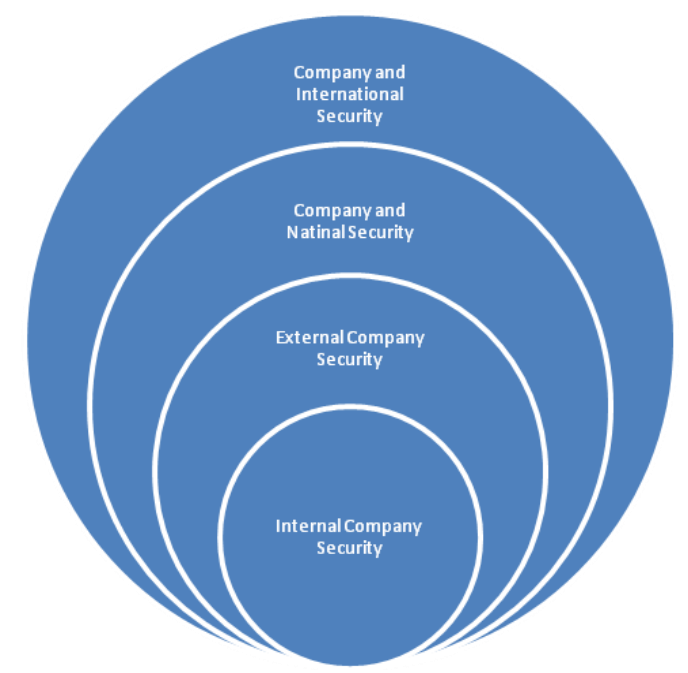

Diagram 2. Company Security ${ }^{3}$

\footnotetext{
${ }^{3}$ Diagram 2, Company Security - Source: author.
} 
New areas related to corporate governance have been developed over time and refer to the security of corporate governance. For example, Business Security has developed from the internal security of the company, and Business Intelligence has evolved from external Company Security. At the same time, some scholars underline that corporate governance framework sets objectives, policies, values, culture, accountabilities and performance. Risk management and security risk management are integral components of effective corporate governance (Smith \& Brooks, 2013. p.33).

\section{INTERNAL COMPANY SECURITY}

Internal security of a company implies those measures and procedures, which are defined by law, as well as the internal regulations of a company which are focused on working within the framework of the company. Above all, it applies the measures of physical and technical protection, fire protection, as well as everything related to the functioning of technology, such as computers and computer systems. If it is necessary, physical - technical protection measures imply guardian service with all the activities typical of this form of protection, the application of cameras and other recording and detection devices, all in order to prevent constantly unauthorized monitoring and unauthorized entry into the workspace. In addition to that, companies can provide significant protection for the important figures and apply self-protection measures that involve the personal accompaniment of one or more persons, depending on the degree of risk and a sense of personal security. In these situations, the company hires specialized agencies or professional employees. For the purpose of personal protection of employees, some companies apply the latest technology, such as different programs installed on mobile phones that are used for warning, and GPS devices with two-way communication, which are installed in wristwatches, mobile phones, personal computers or vehicles, that very precisely determine the position of the employee in the company. One of the essential dilemmas is how to protect computers, computer systems and other means of mass communication such as the Internet, telephone lines and other means of internal and external communication, different models of radio stations, radio connections, etc. Special challenges are all those systems of protection of information, theft or modifying information within the company (intrusion into the software system by Cyber-attacks). Intentionally modified information can cause great damage to the company. For example, a small error in the software in one of the largest automobile company Toyota cost the company billions, not to mention the brand damage for this car manufacturer. Not only did the company have to withdraw all disputed cars, but they also had to pay damages of 1.3 billion USD ${ }^{4}$. Internal company

\footnotetext{
${ }^{4}$ Toyota to pay $\$ 1.3$ billion over deadly brake faults, AAP, http://www.sbs.com.au/news
} /article/2014/03/20/toyota-pay-13-billion-over-deadly-brake-faults, Retrieve 09.04.2019 
focused on the workspace, the objects of work and workers themselves. More and more often companies decide to test their workers using polygraph in certain situations. This happens during the employment, during work or in exceptional circumstances. This will ensure the confidentiality of the work, the outflow of information and company loyalty to corporate - business secrets. Although this method was particularly used by the companies in the United States, with the imposition of The Employee Polygraph Protection Act from 1988, the use of polygraphs by private companies is limited (Dempsey, 2011, p.249). This law mainly refers to the implementation of these methods to workers who perform specific business scope of work such as primary security jobs, work on the manufacturing and distribution of controlled dangerous substances, workers who do confidential jobs and important work of national importance (water-works, nuclear power plants, are important objects of infrastructure, etc.). Considering new security challenges, especially after the terrorist attacks of $9 / 11$, big corporations decided to hire security experts in anti-terrorism, kidnapping or negotiations in crises. In case of crisis, these experts have the duty to protect the employees and the company, as well as to train employees how to act in these circumstances (Halibozek, 2008, p. XI).

\section{EXTERNAL COMPANY SECURITY}

The External Security of a company implies all those processes and activities outside the company which threaten the safety of the company, or its employees. As for the Internal Security of a company, it is also essential to have a proper assessment of the risks and threats that lead to potential dangers. These risks may be related to the endangerment of the company's labor and facilities, or the endangering of the employees in the performance of their work outside the company. Also, certain risks may be related to the important interests of the company, as well as the ability to operate freely domestically or internationally. Certain construction companies, while doing work in dangerous or war-encompassed countries, provide even bulletproof vests for the workers, to protect them from possible attacks. Large multinational companies that perform their business operations on the territory of other countries in extremely dangerous and complex circumstances, producing controversial goods, or just offering similar services, can be an easy target even for terrorists (Halibozek, 2008, p.64). With the escalation of terrorism and the appearance of armed formations of various extremist groups that are capable of kidnapping workers, companies had to adequately respond and implement all the possible measures to protect their employees. For example, forty Indian construction workers been kidnapped from the militant-controlled city of Mosul in northern Iraq ${ }^{5}$. On ${ }^{5}$ India Says 40 Indians Kidnapped in Iraq, Wall Street Journal, http://online.wsj.com/
articles/india-says-it-has-lost-contact-with-40-indians-in-iraq-1403073794 
the other hand, kidnappers once again struck along the creeks of the Niger Delta as four men working for a dredging company attached to a construction giant, Setraco, were abducted along the creek of Nembe, in the Nembe Local Government Area of Bayelsa State ${ }^{6}$. The abduction of the workers who work in dangerous parts of the world has become a serious problem for the companies, in terms of not only human lives and family tragedies, but also in terms of great material losses. The so-called "Sea Pirates" are causing great damage to the economy because they steal entire crews of ocean liners ships and demand ransom for them, and the goods from abducted ships are sold on the black market (Palmer, 2014, p.191). The African coast is especially dangerous because pirates cause enormous damage to the economy all the way from Nigeria in the West, to Somalia in the Northeast. Speaking from personal experience, following the original pictures is a proof that pirates can be extremely dangerous. The attack on a cargo ship Linea Messina took place in November 2010. The pirates were not expecting that the company had hired top anti-terrorist experts, a security service especially for that purpose, and they stopped the pirates' attack. However, other companies have not properly assessed the risk of pirates and terrorists, and they suffered great losses.

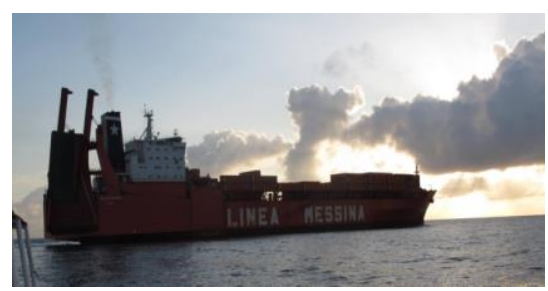

Photo 1. Cargo ship Linea Messina Source Author

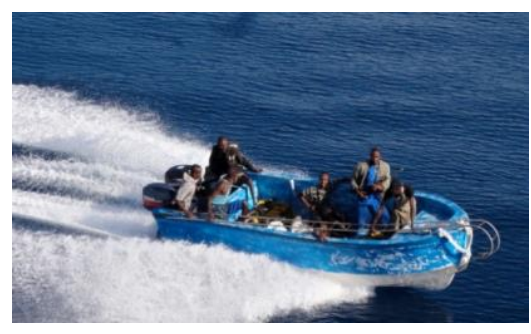

Photo 3. Pirates

Source: author

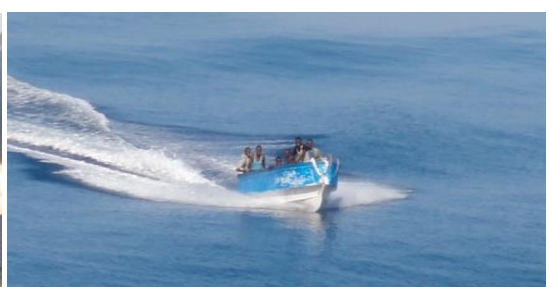

Photo 2. Fishing boat with pirates Source: author

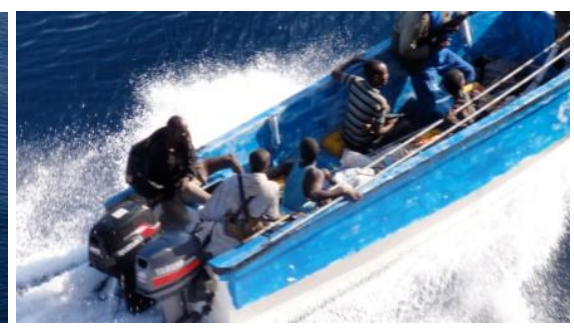

Photo 4. Pirates run after the expert's intervention Source: author

04.09.2019.

${ }^{6}$ Four Setraco Workers kidnapped in Bayelsa, Thisday Live, http://www.thisdaylive.com/ articles/four-setraco-workers-kidnapped-in-bayelsa/186605/ Retrive 05.09.2019. 
The case of Malaysia Airways - the national airline of Malaysia, or better to say the tragedy that struck this company caused tremendous damage. In two separate accidents (the first being the case of the abduction of an aircraft, and another the case of folding passenger aircraft), the company lost two aircrafts and on both occasions, hundreds of passengers lost their lives. Human victims, material damage and the greatly disturbed reputation and brand of this company led Malays Airways to a forced lay-off of more than 6,000 workers, which means that this 42-year-old company is brought to the edge of collapse. ${ }^{7}$ Perhaps this case is an example of a completely ignorant attitude by the company towards external security threats. The first aircraft on the flight, $\mathrm{MH} 370$, was abducted and has not been recovered to this day. I doubt that this is the work of terrorists or the crew members. This is not the first time that a Malaysian plane was abducted. In 1977, a single terrorist abducted the aircraft on the Malaysia Airlines flight, MH 653. The Japanese terrorist, a member of the Japanese Red Army, abducted the aircraft, killed the pilot and then crashed the plane with no survivors (Robertson, 2007, p.354). The question is whether Malaysian Airways has ever had any professionals in charge of security risk assessments? This issue is even more justifiable if we take into consideration the other disaster-related flight, $\mathrm{MH} 17$.

The aircraft was on the flight from Amsterdam to Kuala Lumpur, and was destroyed by a rocket in the war-affected territory between Ukraine and Russia. ${ }^{8}$ Certainly, the business management of the company ignored all warnings related to possible security risks and threats that exist when it comes to the flight over conflict affected territory. The listed examples show the necessity of collecting all available information about the security risks that could jeopardize operations or employees in a company. Different epidemic factors, may also affect the business. This is, for example, the case with the current epidemic of the Ebola virus. In the past, we have seen a range of factors causing panic in investment markets across Africa. The latest worry to investors is the Ebola Virus Disease (EVD) outbreak. The Chief Executive Officer of Financial Derivatives Company (FDC) Limited, Mr. Bismarck Rewane said that the Nigerian economy risks losing over \$3.5billion (circa N542.5bn) to the epidemic if nothing is done to contain the spread. The company mentioned in their recent report that the sectors that will be impacted the most in Nigeria are the aviation, hospitality and tourism,

\footnotetext{
${ }^{7}$ Malaysia Airlines to lose 6,000 jobs in revamp, Daily Star, http://www.dailystar.com.lb/ Business/International/2014/Aug-30/268980-malaysia-airlines-to-lose-6000-jobs-inrevamp.ashx\#axzz3CT1gJoUA Retrieve 05.09.2019

${ }^{8}$ MH17 Malaysia plane crash in Ukraine: What we know, BBC, http://www.bbc.com/ news/world-europe-28357880 Retrieve 05.09.2019.
} 
trade, the medical field and agriculture ${ }^{9}$. The list of risks and threats to companies operating internationally is long and ranges from those risks and threats that come from physical deterrence and the inability to work, to the political instability of the country, or global geopolitical trends. In other words, those risks and threats can be financial risks - inflation or currency crisis, natural disasters such as flooding, earthquakes or uncontrolled fires, political instability or risks, undesirable regulation, expropriation of assets or property by foreign government.

\section{COMPANY AND NATIONAL SECURITY}

The company and National Security determine the role and position of the company with regard to the national security, both the home country of the company, as well as the foreign country where the company is active. It is a primary mission of each state to secure the legal framework of company work, stable economic conditions and safe work. Economic security and stability represent the vital interests of every country. Stable and progressive economy is one of the prerequisites of the defensive possibilities of a country. The weakening of the economic possibilities of one country directly impacts national security. Security can be achieved only by national economy's growth and development (Singh, 1996, p.25). National economy is based on the work of the companies. When it comes to national security, it is extremely important to develop partnerships between the public and private sector. The public and private sectors have a mutual interest in increasing corporate activities to the benefit of homeland security in general and First Responders specifically. In the United States and Europe, large portions of the critical infrastructure lie in the hands of private actors (Steinhausler, 2005. p.121). It is essential to establish the relation between national security and corporate security. Both corporate and national security must be linked by a common national interest. In today's context, corporate security can certainly help national security agencies in many ways and vice versa. For instance, in the US there are three different levels of security hierarchy. National Security (protects the nation with jurisdiction in the US and abroad), Homeland security (protects society with jurisdiction in the US) and Corporate security (protects industrial assets) (Lee E. 2015, p.10).

\footnotetext{
${ }^{9}$ Ebola virus: Imminent danger to banks, investments, Nigerian Tribune, http://tribune. com.ng/business/tribune-business/item/14379-ebola-virus-imminent-danger-to-banksinvestments/14379-ebola-virus-imminent-danger-to-banks-investments Retrieve 05.09.2019
} 


\section{COMPANY AND INTERNATIONAL SECURITY}

Companies and International Security determine the role and position of one company with regard to international security. Moreover, this is primarily the case with multinational companies. The main question here is whether international security affects international trade and vice versa, and if yes, how? Multinational companies operate around the globe, particularly among the less developed countries. That is why multinational companies are often identified as the world's leaders in the exploitation of the poor (Kolodziej, 2005, p.16). By using their power in assets, humans and influence, when it comes to world peace and stability, multinational companies have an important role. For example, multinational companies have an important role in the oil-producing countries and therefore they can very easily trigger a worldwide crisis based on the lack or inadequate delivery of the oil and its derivatives. Particular attention must be paid to the processes of globalization, and how those processes in which multinational corporations participate can have an impact on international and national security. Scholars have long been writing and proving the link between trade, especially international trade and wars. From Plutarch around 100 AD who stated that international commerce brought cooperation and friendship, to the philosophers from the eighteenth and nineteenth centuries, such as Adam Smith, Immanuel Kant, J. J. Rousseau, J. S. Mill, etc., all of them united in the idea that international commerce made war among states costlier (Brooks S, 2005.p.1).

\section{CONCLUSION}

The level of success and economic development of one country can be observed according to the models of corporate governance that are being used. Generally speaking, corporate governance involves the process of managing a company. The transition from the state to the market economy model is almost done in most of the Balkan's countries. Corporate governance system used in socialistic countries is one of the main reasons of the crisis and economic stagnation. However, even though corporate governance is developed in market economies, it is extremely important for us to pay attention to every potential risks for national, or in certain cases, international security. Modern corporate governance contains the answers to every security challenge one of a company. It also implies an entire list of measures from the security aspect, in relation to the potential security risks. Security management of the company detects the security risks, both internal and external. After the risk detection, the next step is to allocate the risk holders, and according to them, determine which steps should be taken with the view of protecting the company. In corporate governance, security can be seen in a narrow and broad sense. In a narrow sense, by security we imply all the measures that are related to the safety within the company. On the other 
hand, the broad security concept involves all the works and processes on the activities outside the company. Moreover, as a broad concept, security can also be seen through the position of one company in the system of national security.

\title{
REFERENCES
}

Eicher, S., (2009), Corruption in International Business: The Challenge of Cultural and Legal Diversity, Gower Publishing, Burlington, US.

Banerjee, B., (2010), Financial Policy and Management Accounting, Ltd. New Delhi, India.

Brink, A., (2011), Corporate Governance and Business Ethics, Springer, London, UK.

Rao, N. P., (1998), Ancient and Modern Precepts in Administration: A Probe Into the Epics, M.D. Publications Pvt. Ltd. New Delhi, India.

Clifton. S., Brooks , D. J., (2013), Security Science: The Theory and Practice of Security, Butterworth-Heinemann, US.

Dempsey, J., (2011), Introduction to Private Security, Cengage Learning, Belmont, US.

Halibozek, E., Jones A., Kovacich G., (2008), The Corporate Security Professional's Handbook on Terrorism, Elsevier, Burlington, US.

Palmer, A., (2014), The New Pirates: Modern Global Piracy from Somalia to the South China Sea, I. B. Tauris, New York, US.

Elsa, L., (2015), Homeland Security and Private Sector Business: Corporations' Role in Critical Infrastructure Protection, Second Edition, CRC Press, US.

Robertson, A., (2007), Terrorism and Global Security, Infobase Publishing, New York, US.

Singh. J., (1996), National Security: An Outline of Our Concerns, Lancer Publishers, New Delhi, India.

Steinhäusler, F., Edwards, F., (2005) NATO and Terrorism Catastrophic Terrorism and First Responders: Threats and Mitigation, Springer, Dordrecht, Netherlands.

Kolodziej, E., (2005), Security and International Relations, Cambridge University Press, Cambridge, UK.

Brooks, S. G., (2005), Producing Security: Multinational Corporations, Globalization, and the Changing Calculus of Conflict, Princeton University Press, US.

\section{НАЦИОНАЛНА И МЕЪУНАРОДНА БЕЗБЕДНОСТ И КОРПОРАТИВНО УПРАВЉАҢЕ}

\author{
Дарко Трифуновић \\ Институт за националну и међународну безбедност, Београд, Србија
}

\section{Резиме}

Процес преласка са друштвеног на акционарско власништво, као и промене у власничкој структури предузећа - постали су извор разних манипулација и злоупотреба, посебно у случају земаља бивше Југославије. Уопштено гледано, корпоративно управљање укључује процес управљања компанијом. Суштина корпоративног управљања односи се на одговорност менаџмента према власницима акција или акционарима. Балканске земље још увек су у фази транзиције и постаје очигледно да се компанијама управља сасвим другачије, пре свега узимајући у 


\section{4}

обзир принципе слободног тржишта. У већини земаља Балкана, процес преласка из државне у тржишну економију је готово завршен. Савремено корпоративно управљање такође укључује одговор на безбедносне изазове са којима је компанија суочена. У међувремену, безбедносни менаџмент постао је део највише хијерархије корпоративног управљања и адекватан одговор на бројне изазове који долазе из ове сфере. Велике мултинационалне компаније које обављају своје пословне операције на територији других земаља у изузетно опасним и сложеним околностима могу бити лака мета чак и за терористе. Посебне изазове представљају сви они системи заштите од крађе или модификације информација (упада у софтверски систем информатичким нападом) у компанији. Савремено корпоративно управљање укључује одговоре на све безбедносне изазове и ризике за једну компанију. Под појмом спољне заштите компаније подразумевају се сви они процеси и активности ван компаније који угрожавају безбедност компаније или њених запослених. Што се тиче унутрашње безбедности компаније, од суштинске важности је исправна процена ризика који доводе до угрожавања. Ови ризици могу бити повезани са угрожавањем циклуса рада или угрожавањем запослених у обављању посла унутар компаније. Основна мисија сваке државе је да осигура правни оквир рада компанија, добре економске услове, те безбедан и сигуран рад. Економска сигурност представља један од виталних интереса сваке земље. Улога државе и државних институција је да на сваки начин заштити своје грађане, компаније и интересе - како унутар државе тако и ван ње. 